\title{
PENGARUH PENGGUNAAN ASAM ASAM ASETAT, ASAM KLORIDA DAN ASAM SITRAT TERHADAP KARAKTERISTIK LEM DARI LIMBAH SISIK IKAN KAKAP MERAH (Lutjanus argentimaculatus)
}

The Effect of the Use of Acetic Acid, Chloride and Citric Acid on the Characteristics of Glue From Red Wheel Waste (Lutjanus argentimaculatus)

\author{
Mariani M.., Haslianti, Suwarjoyowirayatno \\ Jurusan Teknologi Hasil Perikanan, Fakultas Perikanan dan Ilmu Kelautan Universitas Halu Oleo, Kendari, \\ Sulawesi Tenggara, Indonesia \\ *Email korespondensi: marianiany092@gmail.com (Telp: +6282393021171) \\ Diterima: 1 Oktober/ Disetujui 25 November 2020
}

Cara sitasi: Mariani M., Haslianti, Suwarjoyowirayatno. 2020. Pengaruh penggunaan asam asam asetat, asam klorida dan asam sitrat terhadap karakteristik lem dari limbah sisik ikan kakap merah (Lutjanus argentimaculatus). Jurnal Fish Protech. 3(2):184-193.

\begin{abstract}
The aim of this study was to determine the effect of acetic acid, hydrochloric acid, and citric acid on the physical characteristics of glue from red snapper scales. This study used a completely randomized design (CRD) with one factor of the acid solvent type (5\% acetic acid, 5\% hydrochloric acid, and $5 \%$ citric acid with $150 \mathrm{~g}$ of fish scales. Observation data were analyzed using ANOVA (Analysis of Variance) at the $95 \%$ level, if there is a significant difference $(p<0.05)$ then a further test is carried out with the DMRT (Duncan Multiple Range Test) test at the 95\% significant level. The results obtained showed that the effect of acetic acid, hydrochloric acid and citric acid on the characteristics of glue from red snapper fish scales had a significant effect on the adhesive strength value of fish glue, wood surface damage, viscosity, water content but not the $\mathrm{pH}$ of fish glue. The best results for stickiness of fish glue, wood surface damage, fish glue viscosity, $\mathrm{pH}$ and water content were obtained on extraction using asetic acid 6.61; 40.75; 3.60; 4.46; and 48,26 respectively. The results obtained showed that the effect of using acetic acid, hydrochloric acid and citric acid on the characteristics of glue from red snapper fish scales had a significant effect on the adhesive strength value of fish glue, wood surface damage, viscosity, water content but not the $\mathrm{pH}$ of fish glue.
\end{abstract}

Keywords: Acetic acid, citric acid, fish glue, fish scales, hydrochloric acid.

\begin{abstract}
ABSTRAK
Penelitian ini bertujuan untuk mengetahui pengaruh penambahan asam asetat, asam klorida, dan asam sitrat terhadap karakteristik fisik lem dari sisik ikan kakap merah dan untuk mengetahui pengaruh penambahan asam asetat, asam klorida dan asam sitrat terhadap karakteristik kimia lem dari sisik ikan kakap merah. Penelitian ini menggunakan Rancangan Acak Lengkap (RAL) dengan satu faktor yaitu jenis pelarut asam (asam asetat $5 \%$, asam klorida $5 \%$, dan asam sitrat $5 \%$ dengan sisik ikan sebanyak $150 \mathrm{~g}$. Data hasil pengamatan dianalisa menggunakan ANOVA (Analysis of Variance) pada taraf $95 \%$, apabila terdapat beda nyata $(p<0,05)$ maka dilakukan uji lanjut dengan uji DMRT (Duncan Multiple Range Test) pada taraf nyata $95 \%$. Hasil penelitian yang diperoleh menunjukkan bahwa pengaruh penggunaan asam asetat, asam klorida dan asam sitrat terhadap karakteristik lem dari limbah sisik ikan kakap merah memberikan pengaruh nyata terhadap nilai keteguhan rekat lem ikan, kerusakan permukaan kayu, viskositas, kadar air namun tidak dengan $\mathrm{pH}$ lem ikan. Hasil terbaik untuk uji keteguhan rekat lem ikan, kerusakan permukaan kayu, viskositas, pH lem ikan dan kadar air lem ikan terdapat pada ekstraksi menggunakan asam asetat dengan nilai masing-masing 6.61; 40.75 ; $3.60 ; 4.46$ dan 48.26 .
\end{abstract}

Kata kunci: Asam asetat, asam klorida, asam sitrat, lem ikan, sisik ikan 


\section{PENDAHULUAN}

Pada tahun 2015 produksi perikanan tangkap Indonesia berdasarkan jenis ikan, yaitu ikan karang 45,730 ton, ikan cakalang mencapai Sulawesi Tenggara memiliki potensi sumber daya ikan $\pm 500,000$ ton/tahun dengan potensi lestarinya diperkirakan sebesar \pm 250.000 ton yang menghasilkan berbagai jenis ikan pelagis besar, pelagis kecil dan ikan karang (Dinas Kelautan dan Perikanan Provinsi Sulawesi Tenggara, 2015).

Salah satu produk perikanan laut Sulawesi Tenggara adalah ikan kakap merah, ikan kakap merupakan jenis ikan karang dan ikan demersal perairan laut yang mempunyai nilai ekonomis penting dan banyak diminati dengan hasil perikanan tangkap pada tahun 2019, mencapai 19.25 ton (Badan Pusat Statistik Provinsi Sulawesi Tenggara, 2019). Ikan kakap merah juga akan menghasilkan berbagai limbah sebagai hasil samping proses produksinya baik limbah cair maupun limbah padat. Salah satu limbahnya adalah sisik ikan. Senyawa organik pada sisik ikan terdiri dari 40-90 \% dan selebihnya merupakan kolagen (Thidhar, 2016). Limbah industri perikanan memiliki potensi untuk dikembangkan sebagai bahan baku berbagai macam produk olahan yang bermanfaat bagi kebutuhan manusia salah satunya lem ikan.

Lem merupakan salah satu bahan utama yang sangat penting digunakan dalam industri pengolahan kayu. Lem sintesis yang biasa digunakan adalah lem kuning dan lem putih (PVAc). Banyak lem yang menggunakan bahan kimia yang berbahaya dan berasal dari sumberdaya alam tidak terbarukan seperti formaldehid sebagai bahan baku pembuatan resin urea formaldehid (perekat yang banyak digunakan saat ini). Bahan- bahan kimia yang digunakan sebagai bahan dasar pembuat lem adalah termasuk bahan makromolekul (Hartono et al., 1997). Menurut Julian, (2016) Adhesive atau lem adalah zat atau bahan perekat yang digunakan untuk menyatukan dua bagian (sisi) suatu benda. Secara garis besar material pembentuk lem terbuat dari bahan alami maupun bahan sintetis.

\section{Rancangan Penelitian}

Penelitian Aji et al., (2018) pembuatan lem dari tiga jenis tulang ikan yang berbeda menggunakan larutan asam asetat $5 \%$ dan temperature $70 \%$ dengan nilai keteguhan rekat 13,45 , kerusakan kayu 72,29 , viskositas 3,87, kadar air 54,71 dan pH 5,08. Penelitian sebelumnya Wahyudi., (2007) menunjukkan bahwa keteguhan rekat lem yang dihasilkan dengan ekstraksi asam asetat 5\% menggunakan bahan baku tulang ikan pari sebesar $58,09 \mathrm{~kg} / \mathrm{cm}^{2}$ dan tulang ikan cucut sebesar 60,77 $\mathrm{kg} / \mathrm{cm}^{2}$. Penelitian-penelitian sebelumnya Sari et al., (2017) lem ikan menggunakan sisik ikan kakap putih mempunyai nilai keteguhan rekat tertinggi dengan nilai $8.64 \mathrm{~N} / \mathrm{mm}^{2}$, dan keteguhan rekat lem dari sisik ikan bandeng mempunyai nilai terkecil yaitu sebesar 5.61 $\mathrm{N} / \mathrm{mm}^{2}$. Penelitian Rohmah et al., (2015), yang melakukan penelitian pembuatan lem ikan dengan bahan baku tulang ikan bandeng, nila, dan manyung, didapatkan hasil nilai keteguhan rekat lebih rendah dibandingkan dengan lem ikan pari, kakap merah maupun lele. Adapun hasil nilai keteguhan rekat antara lain, lem ikan bandeng sebesar $1.48 \mathrm{~N} / \mathrm{mm} 2$; lem ikan Nila sebesar $5.25 \mathrm{~N} / \mathrm{mm} 2$; dan lem ikan manyung sebesar $6.61 \mathrm{~N} / \mathrm{mm} 2$.

\section{METODE PENELITIAN}

\section{Alat dan Bahan}

Alat-alat yang digunakan dalam penelitian ini yaitu Freezer, talenan, timbangan digital (camry), pipet tetes, Beaker glass (Iwaki), gelas ukur, baskom, thermometer, pengaduk, kain blancu, corong, waterbath (Wisebath), timbangan analitik, rotary vacuum evaporator (IKA RV10 Basic), pH paper (Macherey Nagel).

Bahan yang utama digunakan dalam penelitian ini adalah kakap merah dan Pelarut asam asetat $\left(\mathrm{CH}_{3} \mathrm{COOH}\right)$ (Merck), sodium hidroksida $(\mathrm{NaOH})$ (Merck) dan kayu jati. 
Penelitian ini menggunakan Rancangan Acak Lengkap (RAL) dengan satu faktor yaitu jenis pelarut asam (asam asetat $5 \%$, asam klorida $5 \%$, dan asam sitrat 5\%) dengan sisik ikan sebanyak $150 \mathrm{~g}$.

\section{Prosedur Penelitian}

Preparasi Sampel

Sisik ikan kakap merah diperoleh di Pasar Andounohu, Kecamatan Poasia, Provinsi Sulawesi Tenggara. Preparasi sampel segar sisik ikan kakap merah dilakukan dengan dicuci bersih. Sisik ikan dibawah ke Laboratorium kemudian ditimbang $150 \mathrm{~g}$ dan dilakukan perendaman dengan larutan $\mathrm{NaOH}$ sebelum dilakukan ekstraksi.

\section{Pembuatan Lem Ikan}

Proses pembuatan larutan dilakukan berdasarkan referensi dari penelitian yang dilakukan oleh Sari et al., (2017) dengan metode experimental laboratories diawali dengan tahapan pencucian sisk ikan dan dilakukan proses pre-treatment yaitu perendaman larutan $\mathrm{NaOH}$.

Tahap pendahuluan ini meliputi pengambilan sisik ikan kakap merah setelah pengambilan sisik dilakukan pencucian sisik sebanyak 1 kali untuk menghilangkan dari kotoran, kemudian sisik ikan ditimbang masing-masing 3 perlakuan sebanyak $50 \mathrm{~g}$ lalu dilakukan proses pre-treatment, yaitu dengan melakukan perendaman dengan menggunakan sodium hidroksida $(\mathrm{NaOH})$ dengan perbandingan sisik ikan: larutan $\mathrm{NaOH} 0.1 \mathrm{M}$ (1:3). Perendaman dilakukan selama 6 jam dan setiap 3 jam larutan $\mathrm{NaOH}$ diganti. Setelah perendaman sisik dicuci hingga $\mathrm{pH}$ netral. Tahap utama ekstraksi menggunakan tiga jenis larutan asam terdiri dari asam asetat 5\%, klorida 5\% dan asam sitrat $5 \%$ selama 4 jam dengan suhu 65 $70^{\circ} \mathrm{C}$. Hasil ekstraksi disaring dan didinginkan sampai suhu ruang, kemudian dilakukan pemekatan dengan rotary evaporator sampai pekat dan dihasilkan lem ikan yang murni, kemudian dianalisis viskositas, $\mathrm{pH}$, kadar air, dan diuji coba kekuatan rekatnya.

\section{Variabel Pengamatan}

Variabel pengamatan pada penelitian ini terdiri dari uji kerekatan (BSN, 1999), uji kerusakan permukaan kayu (Burhanuddin et al., 2016), uji viskositas (Muljana et al., 2005), uji derarajat keasaman (Muljana et al., 2005 dan uji kadar air (AOAC, 2005).

\section{Analisis Data}

Analisis data yang digunakan dalam penelitian ini adalah dengan menggunakan sidik ragam Analisis of Varian (ANOVA) dan jika hasil analisis terdapat perbedaan nyata, maka dilanjutkan dengan uji lanjut Duncan Multiple Range Test (DMRT) pada taraf kepercayaan 95\% ( $a=0,05)$.

\section{HASIL DAN PEMBAHASAN}

Hasil analisis keteguhan rekat (uji kering), analisis kerusakan permukaan kayu, viskositas, Derajat Keasaman (pH), dan kadar air lem ikan dari tiga jenis asam yang berbeda tersaji pada Tabel dibawah ini.

Tabel 1. Keteguhan rekat lem ikan dengan tiga jenis asam yang berbeda

\begin{tabular}{lcc} 
Jenis asam & Keteguhan Rekat $\left(\mathrm{N} / \mathrm{mm}^{2}\right)$ & DMRT \\
\hline Asetat & $6.61 \pm 0,19 \mathrm{c}$ & \\
Klorida & $4.10 \pm 0,47^{\mathrm{a}}$ & $2=2,05$ \\
Sitrat & $5.62 \pm 0,32^{\mathrm{b}}$ & $3=2,25$ \\
Lem komersial $^{*}$ & $6.65 \pm 0,23$ & $4=2,26$
\end{tabular}

Keterangan: Angka yang diikuti huruf yang sama menunjukkan hasil yang tidak berbeda nyata dengan taraf signifikan $(a=0,05)$. 
Tabel 2. Kerusakan permukaan kayu lem ikan dengan tiga jenis asam yang berbeda

\begin{tabular}{lcc}
\hline Jenis asam & Kerusakan kayu (\%) & DMRT \\
\hline Asetat & $40.75 \pm 0,90^{c}$ & \\
Klorida & $15.43 \pm 2,06^{\mathrm{a}}$ & $2=2,10$ \\
Sitrat & $26.62 \pm 0,92^{\mathrm{b}}$ & $3=2,15$ \\
${\text { Lem } \text { komersial }^{*}}$ & $46.65 \pm 0,56$ & $4=2,25$ \\
\hline
\end{tabular}

Keterangan: Angka yang diikuti huruf yang sama menunjukkan hasil yang tidak berbeda nyata dengan taraf signifikan $(a=0,05)$.

Tabel 3. Viskositas lem ikan dengan tiga jenis asam yang berbeda

\begin{tabular}{lll}
\hline & & \\
Jenis asam & Viskositas (poise) & \\
\hline Asetat & $3.60 \pm 0,25^{\mathrm{a}}$ & \\
Klorida & $4.33 \pm 0.04^{\mathrm{c}}$ & $2=0,25$ \\
Sitrat & $3.72 \pm 0.26^{\mathrm{b}}$ & $3=0,46$ \\
Asetat (Sari et al., 2017) & $7.68 \pm 0.32$ & \\
\hline
\end{tabular}

Keterangan: Angka yang diikuti huruf yang sama menunjukkan hasil yang tidak berbeda nyata dengan taraf signifikan $(a=0,05)$.

Tabel 4. Derajat keasaman $(\mathrm{pH})$ lem ikan dengan tiga jenis asam yang berbeda

\begin{tabular}{lcc}
\hline Jenis asam & Derajat Keasaman $(\mathrm{pH})$ & DMRT \\
\hline Asetat & $4.46 \pm 0,61^{\mathrm{a}}$ & \\
Klorida & $4.64 \pm 0,06^{\mathrm{a}}$ & $2=2,40$ \\
Sitrat & $4.75 \pm 0,61^{\mathrm{a}}$ & $3=2,45$ \\
Asetat (Sari et al., 2017) & $4.80 \pm 0.10$ & \\
\hline
\end{tabular}

Keterangan: Angka yang diikuti huruf yang sama menunjukkan hasil yang tidak berbeda nyata dengan taraf signifikan $(a=0,05)$.

Tabel 5. Kadar air Lem lkan dengan Tiga Jenis Asam yang Berbeda

\begin{tabular}{lll}
\hline Jenis asam & Kadar Air & DMRT \\
\hline Asetat & $48,26 \pm 0.12^{\mathrm{a}}$ & \\
Klorida & $59,06 \pm 0.68^{\mathrm{c}}$ & $2=2,30$ \\
Sitrat & $56,72 \pm 0,31^{\mathrm{b}}$ & $3=2,35$ \\
Asetat (Sari et al., 2017) & $59.06 \pm 0.78$ & \\
\hline
\end{tabular}

Keterangan: Angka yang diikuti huruf yang sama menunjukkan hasil yang tidak berbeda nyata dengan taraf signifikan ( $a=0,05)$. 


\section{Keteguhan Rekat Lem Ikan}

Hasil penelitian lem menggunakan sisik ikan menunjukkan nilai tertinggi terdapat pada asam asetat $\left(6.61 \mathrm{~N} / \mathrm{mm}^{2}\right)$ dan nilai terendah pada asam klorida (4.10 N/mm²) tidak jauh berbeda dengan hasil pengujian menggunakan lem komersial dengan nilai 6.65 menunjukkan tidak adanya perbedaan nyata. Hal ini diduga penggunaan jenis asam berbeda, larutan hasil ekstraksi dengan klorida tidak membentuk gel bila didinginkan, berbeda halnya dengan larutan yang dihasilkan dengan asam asetat. Gel tersebut diduga merupakan gelatin yang terlarut yang menunjukkan proses estraksi dengan asam asetat telah berhasil. Hal tersebut juga ditunjukkan melalui nilai viskositas lem ikan hasil ekstraksi asam asetat yang sedikit lebih besar dari lem ikan hasil ekstraksi dengan klorida.

Ekstraksi dengan asam klorida diduga menyebabkan kolagen terhidrolisis terlalu kuat, sehingga gel yang diperoleh terdegradasi menjadi protein yang lebih sederhana. Hasil ekstraksi menggunakan asam klorida sisik ikan tidak menghasilkan residu ekstraksi sehingga daya rekat lem ikan menurun. Penggunaan asam sitrat pada proses ekstraksi mengalami perbedaan diduga karena sifat kereaktifan dari jenis asam organik paling kuat kereaktifannya, sehingga akan lebih banyak mengikat komponen mineral dibandingkan asam asetat dan klorida. Hal ini didukung pernyataan Ismangil dan Hanudin (2005) dalam Priyandi, et al., (2013) kereaktifan asam merupakan daya gabung dari anion organik dengan kation, sifat asam yang lebih reaktif akan lebih banyak mengikat komponen mineral dibandingkan dengan asam asetat dan klorida yang memiliki sifat kereaktifan yang lemah. Hal ini dikarenakan jumlah gelatin terlarut dalam lem ikan tidak terlalu besar, yang diduga jumlah kolagen dalam umpan yang sudah terhidrolisis optimum dan juga dipengaruhi oleh jenis asam yang digunakan pada proses ekstraksi. Menurut Tony et al., ( 2011), kekuatan rekat dipengaruhi oleh kadar gelatin dalam fish glue, semakin tinggi kadar gelatin akan semakin kuat daya rekatnya.

Ketiga jenis lem ikan tersebut semuanya memenuhi standar SNI PVAc sebagai pembanding standar. Menurut SNI 06-6049-1999, perekat polivinil asetat emulsi untuk pengerjaan kayu disyaratkan memiliki keteguhan rekat minimal $3 \mathrm{~N} / \mathrm{mm} 2$ (BSN, 1999). Perekat polivinil asetat emulsi untuk pengerjaan kayu disyaratkan memiliki keteguhan rekat minimal 3 $\mathrm{N} / \mathrm{mm} 2$. Berdasarkan penelitian Sari et al., (2017) lem ikan menggunakan sisik ikan kakap putih mempunyai nilai keteguhan rekat tertinggi dengan nilai 8.64 $\mathrm{N} / \mathrm{mm}^{2}$, dan keteguhan rekat lem dari sisik ikan bandeng mempunyai nilai terkecil yaitu sebesar 5.61 $\mathrm{N} / \mathrm{mm}^{2}$. Penelitian Rohmah et al., (2015), yang melakukan penelitian pembuatan lem ikan dengan bahan baku tulang ikan bandeng, nila, dan manyung, didapatkan hasil nilai keteguhan rekat lebih rendah dibandingkan dengan lem ikan pari, kakap merah maupun lele. Adapun hasil nilai keteguhan rekat antara lain, lem ikan bandeng sebesar $1.48 \mathrm{~N} / \mathrm{mm} 2$; lem ikan Nila sebesar $5.25 \mathrm{~N} / \mathrm{mm} 2$; dan lem ikan manyung sebesar $6.61 \mathrm{~N} / \mathrm{mm} 2$.

\section{Kerusakan Permukaan Kayu}

Berdasarkan hasil yang diperoleh menunjukkan adanya tingkat kerusakan permukaan kayu yang tinggi dari setiap lem ikan dengan jenis asam berbeda, dan didapatkan hasil paling besar adalah asam asetat dengan nilai 40.75 dan terendah terdapat pada asam klorida dengan nilai 15.43 tidak jauh berbedah hasil pengujian menggunakan lem komersial dengan nilai 46.65 menunjukkan tidak adanya perbedaan nyata. $\mathrm{Hal}$ ini diduga penggunaan jenis asam berbeda berpengaruh terhadap tingkat kerusakan kayu.

Menurut Xiao et al., (2007), dari hasil uji geser, selain keteguhan rekat, persentase kerusakan pada permukaan kayu juga dihitung. Prinsip dalam pengukuran persentase kerusakan permukaan kayu adalah perekat yang merekat pada permukaan kayu diasumsikan lebih kuat daripada substrat kayu tersebut. Oleh karena itu, pengukuran kerusakan permukaan kayu setelah uji geser merupakan indikator yang mendukung keteguhan rekat. Kerusakan permukaan kayu biasanya merupakan indikasi dari keteguhan rekat dari perekat yang digunakan, dengan persentase kerusakan permukaan 
kayu yang tinggi, menunjukkan bahwa keteguhan rekat dari perekat lebih kuat daripada kayu itu sendiri.

Pengujian kerekatan perekat untuk mengetahui efektifitas perekat terhadap bahan yang direkatkan. Persentase kerusakan kayu salah satu kriteria penilaian lem. Nilai kerusakan kayu dipengaruhi oleh nilai keteguhan rekat. Persentase kerusakan kayu yang tinggi disebabkan oleh tingginya nilai keteguhan rekat sehingga menghasilkan kualitas perekatan yang tinggi dan sebaliknya apabila nilai keteguhan rekat rendah maka nilai kerusakan permukaan kayu rendah. Menurut Saleh et al., (1995), persentase kerusakan kayu merupakan salah satu kriteria penilaian mutu perekat dan perekatan. Persentase kerusakan kayu yang tinggi disebabkan karena tingginya keteguhan rekat lem sehingga menghasilkan kualitas perekatan yang tinggi. Semakin tinggi persentase kerusakan kayu maka semakin baik kualitas lem ikan karena berarti mempunyai kekuatan rekat yang tinggi.

Menurut Sipayung, (1982) dalam Wahyudi, (2007) jenis kayu dan ketebalan kayu berpengaruh terhadap keteguhan rekat, termasuk keteguhan geser dan kerusakan kayu. Lebih lanjut menurut Purwadi, (1999), proses kerekatan mengakibatkan kerusakan permukaan karena masuknya cairan perekat ke dalam pori-pori bahan yang direkatkan dan kemudian mengeras karena proses perekatan mekanis dengan adanya gaya kohesi antara molekul perekat dengan molekul bahan yang direkatkan.

Berdasarkan penelitian Sari et al., (2017) lem ikan menggunakan sisik ikan Kakap mempunyai nilai kerusakan kayu tertinggi dengan nilai 40.47 sedangkan kerusakan kayu dari sisik ikan Bandeng mempunyai nilai terkecil yaitu 31.05. Seperti pada penelitian yang dilakukan Sulistyanto et al., (2015), yang menggunakan tiga jenis tulang ikan yang berbeda, mendapatkan hasil terbesar pada ikan tongkol yaitu $83.21 \%$, ikan tenggiri $72.23 \%$, dan pada ikan cobia sebesar $62.07 \%$. Penelitian Nugroho et al., (2015) lem ikan yang menggunakan tiga tulang ikan laut yang berbeda memiliki hasil kerusakan permukaan kayu sebesar $37.75 \%$ pada ikan Swangi, $28.82 \%$ pada ikan kurisi dan paling kecil pada ikan kuniran, yaitu sebesar $15.43 \%$.

\section{Viskositas (kekentalan) Lem Ikan}

Hasil pengamatan viskositas menggunakan asam klorida terlalu kental sehingga membuat lem sulit menyerap masuk pada pori-pori bidang rekat (kayu jati) dan hanya mengumpal pada permukaan saja. Hasil pengamatan viskositas menggunakan asam sitrat terlalu encer sehingga lem akan hanya masuk ke dalam pori-pori bidang rekat tanpa merekat pada bidang rekat jauh berbeda dengan hasil penelitian Sari et al., (2017) menggunakan bahan baku sisik ikan kakap putih yang terbaik dengan nilai 7.68. Menurut Widiyanto, (2011) viskositas menunjukkan kemampuan perekat untuk mengalir dari suatu permukaan ke permukaan yang lain pada kayu yang direkat untuk membentuk suatu lapisan yang kontinu, menyebar merata pada seluruh permukaan.

Menurut BSN, (1999) perekat polivinil asetat emulsi untuk pengerjaan kayu disyaratkan memiliki derajat kekentalan minimal 1,0 poise (SNI 0660491999). Lem ikan tersebut telah memenuhi standar SNI PVAc sebagai pembanding standar. Maka dapat diketahui bahwa viskositas dengan nilai sebesar 3,60 poise pada lem ikan mendapatkan cukup baik dalam menghasilkan nilai rekat lem ikan dari sisik. Hal ini didukung oleh pernyataan Swastawati et al., (2007) penggunaan asam asetat pada pembuatan lem ikan memberikan kontrol viskositas sehingga mampu menciptakan lapisan perekat yang tipis dan seragam.

Penelitian yang dilakukan Van et al., (2017), juga menunjukkan jika nilai daya rekat terbesar yang didapat dari lem ikan berbahan dasar kulit ikan kakap yaitu sebesar $6.05 \mathrm{~N} / \mathrm{mm}^{2}$ akan mempunyai nilai viskositas yang paling rendah, yaitu sebesar 3.85 poise. Viskositas berbanding terbalik dengan keteguhan rekat. Semakin rendah viskositas, maka semakin cepat perekat merembes ke dalam sel kayu, sehingga keteguhan rekat semakin kuat. Selain itu, viskositas juga berpengaruh terhadap $\mathrm{pH}$ perekat.

Menurut Sulistyanto et al., (2015) nilai viskositas pada lem ikan merupakan salah satu faktor penting dalam menentukan kualitas lem karena nilai viskositas mempengaruhi nilai keteguhan rekat. Semakin rendah nilai viskositas, maka nilai keteguhan rekat semakin tinggi. Lem yang baik adalah lem yang memiliki bentuk 
yang tidak terlalu kental, namun juga tidak terlalu encer. Lem yang viskositasnya rendah, akan meningkatkan kualitas perekatan kayu yang dihasilkan. Menurut Widiyanto, (2011) semakin kecil viskositas perekat maka semakin besar kemampuan perekat untuk mengalir, berpindah dan mengadakan penetrasi serta pembasahan. Tetapi jika viskositas perekat terlalu rendah (encer) akan menyebabkan rendahnya nilai keteguhan rekat

\section{Derajat Keasaman (pH) Lem Ikan}

Berdasarkan hasil penelitian nilai $\mathrm{pH}$ tertinggi didapatkan pada lem ikan dari asam klorida yaitu sebesar 4.75, sedangkan nilai $\mathrm{pH}$ terendah didapatkan oleh lem ikan dari asam asetat yaitu sebesar 4.46. Nilai pH yang terbaik didapatkan pada penggunaan asam asetat dengan nilai 4.46. Ketiga jenis lem ikan tersebut telah memenuhi standar SNI PVAc sebagai pembanding standar.

Menurut BSN, (1999) perekat polivinil asetat emulsi untuk pengerjaan kayu disyaratkan memiliki derajat keasaman $(\mathrm{pH})$ sebesar 3-8 (SNI 06-60491999). Nilai pH berpengaruh terhadap kestabilan derajat kekentalan perekat karena perekat ikan yang dibuat ini merupakan hasil ekstraksi kolagen dari sisik ikan kakap merah dengan jenis asam yang berbeda. Tetapi pada Tabel 4 hasil analisis statistik menunjukkan bahwa nilai $\mathrm{pH}$ dari tiga jenis asam berbeda tidak berpengaruh nyata terhadap nilai $\mathrm{pH}$ secara signifikan tidak jauh berbeda dengan hasil penelitian Sari et al., (2017) menggunakan bahan sisik ikan kakap putih yang terbaik dengan nilai $\mathrm{pH} 4.80$. Hal ini didukung oleh pernyataan Aji et al., (2018) nilai $\mathrm{pH}$ dari lem ikan yang dihasilkan akan berhubungan dengan bahan pengekstrak dari lem yaitu larutan asam asetat. Larutan asam asetat terkandung pada lem ikan ini tidak hanya berfungsi unttuk mengikat kolagen pada sisik namun juga dapat menghambat pertumbuhan bakteri yang dapat merusak kualitas lem ikan dan juga dapat memperpanjang masa simpan lem ikan (Sari et al., 2017).

Berdasarkan penelitian Aji et al., (2018) yang melakukan penelitian perbandingan kualitas lem ikan dari tiga jenis tulang ikan yang berbeda dengan nilai
$\mathrm{pH}$ tertinggi terdapat pada bahan baku tulang ikan pari yaitu sebesar 5.65 , dan nilai $\mathrm{pH}$ terendah terdapat pada tulang ikan kakap yaitu sebesar 5.08. Rohmah et al., (2015) yang melakukan penelitian pembuatan lem ikan dengan bahan baku tulang ikan bandeng, nila dan manyung didapatkan hasil nilai derajat keasaman $(\mathrm{pH})$ yang sedikit berbeda dengan lem ikan pari, kakap, maupun Lele. Adapun hasil nilai derajat keasaman $(\mathrm{pH})$ antara lain, lem ikan bandeng sebesar 4.4; lem ikan nila sebesar 4.5; dan lem ikan manyung sebesar 4.6.

\section{Kadar Air}

Air merupakan salah satu unsur penting dalam bahan pangan. Semua bahan makanan dan non makanan mengandung air dalam jumlah yang berbeda-beda, baik itu bahan makanan hewani maupun nabati. Penentuan kadar air merupakan analisis paling penting dan paling luas dilakukan dalam pengolahan dan pengujian pangan. Kadar air berpengaruh secara langsung terhadap stabilitas dan kualitas pangan. Hasil analisis kadar air dari tiga jenis asam berbeda dapat dilihat pada Tabel 5 .

Nilai kadar air yang terbaik terdapat pada asam asetat yaitu $48.26 \%$ tidak jauh berbeda dengan hasil penelitian Sari et al., (2017) menggunakan bahan baku sisik ikan kakap putih yang terbaik dengan nilai kadar air 59.06. Hal ini dipengaruhi oleh beberapa faktor yang membuat kadar air lem ikan berbeda, seperti suhu ekstrasi, penggunaan jenis asam saat ekstraksi. Ekstraksi sisik ikan dalam penelitian menggunakan suhu $70^{\circ} \mathrm{C}$ saat melakukan pemekatan dengan rotary evaporator. Penggunaan suhu tinggi bertujuan untuk menghilangkan kadar air pada sisik dan untuk mempermudah pengeluaran kolagen dari dalam sisik ikan. Selain itu pengaruh suhu ekstraksi sangat berpengaruh pada kadar air yang akan dihasilkan. Karena suhu ekstraksi yang tinggi akan menurunkan kadar air. Air akan terhidrolisis dan terdegradasi. Hal ini didukung oleh pernyataan Sompie et al., (2015), nilai kadar air cenderung menurun dengan semakin meningkatnya suhu ekstraksi. Menurunnya kadar air akibat suhu ekstraksi yang tinggi disebabkan karena proses denaturasi yang terjadi akan mengakibatkan 
perubahan molekul dan jumlah air yang terikat menjadi lebih lemah dan menurun.

Berdasarkan penelitian Swastawati et al. (2007), lem ikan yang diproses dalam bentuk cair mengandung $45-55 \%$ air, dan berbentuk lembaran pada keadaan padat. Kadar air lem sangat erat dengan nilai keteguhan rekat. Nilai kadar air lem ikan berbanding terbalik dengan nilai keteguhan rekat. Perekat/lem yang memiliki kadar air tinggi akan menyebabkan nilai keteguhan rekat menjadi menurun. Menurut Mawardi, (2009) kadar air yang terlalu tinggi menyebabkan ikatan rekat menjadi lemah. Penggunaan larutan asam juga merupakan salah satu faktor yang mempengaruhi kadar air, karena pelarut asam dapat mengikat air saat proses ekstraksi sehingga menyebabkan senyawa air air akan terikat.

Berdasarkan penelitian Rohmah, (2015) melakukan pembuatan lem ikan dengan bahan baku tulang ikan bandeng, nila dan manyung didapatkan hasil nilai kadar air antara lain, lem ikan bandeng sebesar $41.87 \%$, lem ikan nila sebesar $49,13 \%$, lem ikan manyung sebesar $54.84 \%$ dan penelittian yang dilakukan Aji et al., (2018) lem ikan dengan bahan baku tulang ikan lele mempunyai nilai tertinggi yaitu 65.51 dan nilai terendah terdapat pada bahan baku tulang ikan pari yaitu 49.03 .

\section{Kerenyahan}

Kerenyahan selalu berbanding lurus dengan tekstur. Hasil uji organoleptik menunjukkan bahwa rerata nilai kerenyahan pada kerupuk dengan perbandingan ikan layang dan rumput laut terhadap perlakuan yang diberikan dapat meningkatkan kerenyahan pada kerupuk. Kerupuk pada perlakuan P4 memiliki nilai rerata tertinggi sebesar 4,3, sedangkan kerupuk pada perlakuan P1 memiliki nilai rerata terendah yaitu 3,7. Hal tersebut disebabkan karna banyaknya jumlah kosentrasi ikan pada perlakuan P1 sehingga memiliki protein yang cukup tinggi dibandingkan kerupuk lainnya. Menurut Istanti (2005) menyatakan kandungan protein yang tinggi dapat menyebabkan kantong-kantong udara kerupuk yang dihasilkan semakin kecil karena padatnya kantong-kantong udara tersebut terisi oleh bahan lain yaitu daging ikan yang banyak mengandung protein sehingga dapat menyebabkan daya kembang semakin kecil yang akhirnya dapat menyebabkan kerenyahan semakin menurun.

\section{KESIMPULAN}

Berdasarkan hasil penelitian dan pembahasan, maka dapat disimpulkan sebagai berikut:

1. Pengaruh penggunaan asam asetat, asam klorida dan asam sitrat terhadap karakteristik fisik lem dari limbah sisik ikan kakap merah menunjukk an bahwa nilai keteguhan rekat lem ikan terbaik terdapat pada asam asetat dengan nilai yaitu 6.61 $\left(\mathrm{N} / \mathrm{mm}^{2}\right)$, kerusakan kayu terbaik terdapat pada asam asetat dengan nilai $4075 \%$, dan viskositas lem ikan terbaik terdapat pada asam asetat dengan nilai 3.60 poise.

2. Pengaruh penggunaan asam asetat, asam klorida dan asam sitrat teerhadap karakteristik kimia lem ikan dari limbah limbah sisik ikan kakap merah menunjukkan bahwa nilai $\mathrm{pH}$ terbaik terdapat pada asam asetat dengan nilai 4.46 dan nilai kadar air terbaik terdapat pada asam asetat dengan nilai 48.26

\section{DAFTAR PUSTAKA}

Astawan, M. dan T. Aviana. 2003. Pengaruh jenis larutan Perendaman Serta Metode Pengeringan Terhadap Sifat Fisik, kimia dan fungsional gelatin dari kulit Ikan Cucut. Jurnal. Teknol. dan Ind. Pangan. 16 (1):7-13.
Association of Official Analytical Chemist [AOAC]. 2005. Official Methods of Analysis (18 Edn). Association of Official Analytical Chemist Inc. Mayland. USA.

Ali F., Ferawati, dan R. Arqomah. 2013. Ekstraksi Zat Warna Dari Kelopak Bunga Rosela (Studi 
Pengaruh Konsentrasi Asam Asetat dan Asam Sitrat). Jurnal Teknik Kimia 1 (19) : 26-34.

Aji G., I. Y. S Darmanto. R., A. Kurniasih. 2018.

Perbandingan Kualitas Lem Ikan dari Tiga Jenis

Tulang Ikan yang Berbeda. Jurnal IImiah Tknosains, Vol 4 (1).

Badan Standardisasi Nasional, 1999. Standar Nasional Indonesia Tentang Polivinil Asetat Emulsi untuk Perekat Pengerjaan Kayu. SNI 066049-1999. Jakarta.

Boonprab, K., J. Satiankomsorakrai, and N. Khamthong. 2011. Optimum fish for fish glue processing for fish skin value added and the glue character. J. Agricultural Science and Technology, 1(8B):1211-1215.

Handoko, T., Sherly O. R., dan Isabella S. 2011. Pengaruh Jenis dan Konsentrasi Asam, Temperatur dan Waktu Ekstraksi terhadap Karakteristik Fish Glue dari Limbah Ikan Tenggiri. Jurnal Reaktor. 13 (4) : 237-241.

Hartati, I dan L. Kurniasari. 2010. Kajian Produksi Kolagen dari Limbah Sisik Ikan Secara Ekstraksi Enzimatis. Jurnal Momentum. Vol 6 (1):Hal 33-35.

Hermanto, S., M. R. Hudzaifah, dan A. Muawanah. 2014. Karakteristik Fisikokimia Gelatin Kulit Ikan Sapu-Sapu (Hyposarcus pardalis) Hasil Ekstraksi Asam. Jurnal Kimia Valensi. Vol 4 (2):Hal.109-120.

Ismangil dan Hanudin E. 2005. Degradasi Mineral Batuan oleh Asam-asam Organik. Jurnal IImu Tanah dan Lingkungan Vol. 5(1) p: 1-17.

Juliasti, R., A. M. Legowo, Y. B. Pramono. 2014. Pengaruh Konsentrasi Perendaman Asam Klorida pada Limbah Tulang Kaki Kambing Terhadap Kekuatan Gel, Viskositas, Warna dan Kejernihan, Kadar Abu dan Kadar Protein Gelatin. Jurnal Teknologi Hasil Pertanian. Vol. 7 (1): Hal 32-38.

KKP, 2018. Statistik Perikanan Tangkap Sulawesi Tenggara. Kementrian Kelautan dan Perikanan. Jakarta.

Lazuardi, R.N.M.2010. Mempelajari Ekstraksi Pigmen Antosianin dari kulit Manggis (Garcinia mangostana, L.) dengan Berbaagai Jenis Pelarut. [Skripsi]. Fakultas Teknik. Universitas Pasundan. Bandung. $61 \mathrm{Hal}$.

Muljana, H. Handoko, T. Nelly, Febrianti, Winny, M. 2005. Kajian Awal Pembuatan Fish Glue dari Berbagai Limbah Ikan. [Skripsi]. Lembaga
Penelitian dan Pengabdian Kepada Masyarakat, Universitas Katolik Parahyangan Bandung.

Maryani. 2010. Pengaruh Faktor Jenis Kertas, Jenis Perekat, dan Kerapatan Komposit Terhadap Kekuatan Impak Pada Komposit Panel Serap Bising Berbahan Dasar Limah Kertas. [Skripsi]. Jurusan Teknik Industri, Fakultas Teknik, Universitas Sebelas Maret, Surakarta.

Mawardi, I. 2009. Mutu papan partikel dari kayu kelapa sawit (KKS) berbasis perekat polystyrene. J. Teknik Mesin, 11(2):91-96.

Purwadi, T. 1999. Pengkajian Mutu dan TeknoEkonomi Perekat dari Tulang Ikan. [Skripsi]. Program Studi Teknologi Pasca Panen, Institut Pertanian Bogor, Bogor.

Purba, R. 1994. Perkembangan Awal Ikan Kakap Merah (Lutjanus Argentimaculatus). Jurnal Oseana. Vol 19 (3): Hal. 11 - 20.

Pertiwi, M. Atma, Y. Mustopa, Z. A. Maizarah, R. 2018. Karakteristik Fisik dan Kimia Gelatin dari Tulang Ikan Patin dengan PreTreatment Asam Sitrat. Jurnal Aplikasi Teknologi Pangan. Vol 7 (2): Hal. 83-91.

Rohmah, D. Y. N., Y. S. Darmanto, dan U. Amalia. 2015. Karakteristik Lem dari Tulang Ikan dengan Habitat yang Berbeda (Payau, Tawar, Laut). Jurnal Pengolahan dan Bioteknologi Hasil Perikanan. Vol 4(2):Hal.11-16.

Sari, K. D. Darmanto, S. Y., U. Amalia. 2017. Pemanfaatan Limbah Hasil Perikanan: Lem Ikan Berbahan Baku Sisik lkan yang Berbeda. Jurnal IImu Pangan dan Hasil Pertanian.Vol. 1 (2): Hal. 60-71.

Swastawati, F., A. S. Fahmi, dan P. H. Riyadi. 2007. Pemanfaatan Limbah Hasil Perikanan. Badan Penerbit Universitas Diponegoro. Semarang.

Sulistyanto, E. P., Y. S. Darmanto, dan U. Amalia. 2015. Karakteristik Lem Ikan dari Tiga Jenis Ikan Laut yang Berbeda. JITKT. Vol 7(1). Hal. 23-31.

Setyowati, H. dan W. Setyani. 2015. Potensi Nanokolagen Limbah Sisik Ikan Sebagai Cosmeceutical. Jurnal Farmasi Sains dan Komunikasi. Vol 12 (1).

Sri, H. 2009. Metode Perekatan dengan Lem Pada Sambungan Pelebaran Kayu. Jurnal Teknik Sipil dan Perencanaan, Vol 11 (1). Hal. 11-20.

Suriani, S., Soemarno, dan Suharjono. 2013. Pengaruh Suhu dan $\mathrm{pH}$ terhadap Laju 
Pertumbuhan Lima Isolat Bakteri Anggota Genus Pseudomonas yang diisolasi dari Ekosistem Sungai Tercemar Deterjen di Sekitar Kampus Universitas Brawijaya. Jurnal Pembangunan dan Alam Lestari. 3 (2): 58-62.

Sompie, M., A. D. Mirah dan L. CH. M. Karisoh, 2015.

Pengaruh Perbedaan Suhu Ekstraksi Terhadap

Karakteristik Gelatin Kulit Kaki Ayam. Pros Sem Nas Biodiv Indon. Vol 1(4):Hal.792-795.

Saleh, M., R.S. Embun, S. Wijandi, dan N. Haq . 1995.

Ekstraksi Lem Ikan dari Tulang Ikan Pari. Jurnal Penelitian Perikanan Indonesia, 1 (2): 28-38.

Tridhar, A. N. 2016. Perbandingan Produksi Kolagen

Dari Sisik dan Tulang Ikan Gurami (Osphronemus gouramy) Secara Kimia dan Enzimatis. [Skripsi]. Program Studi Teknologi Pangan, Fakultas Teknik, Universitas Pasundang Bandung.

Tony, H. Sherly, O. R, Isabella, S. 2011. Pengaruh Jenis dan Konsentrasi, Asam, Temperatur dan Waktu Ekstraksi Terhadap Karakteristik Fish Glue dari Limbah Ikan Tenggiri. Jurnal Reaktor, Vol 13 (4) Hal. 237.241.

Tambunan, R. V. Darmawanto, S. Y. Anggo., D. A. 2017. Pengaruh Dari Berbagai Jenis Kulit Ikan Terhadap Keteguhan Rekat, Kerusakan Permukaan Kayu, dan Viskositas Pada Lem Ikan. Jurnal Peng. \& Biotek. Hasil P.Vol. 6 (3): Hal. 15-19.
Wahyuningsih, M., Soeryono., Soedarsono. 1991. Laporan Penelitian Pemanfaatan Limbah Padat Industri Penyamakan Kulit untuk Glue. Jurnal $B P P I$, Semarang.

Widyasmara, T. 2007. Pengaruh Lama Waktu Perebusan yang Berbeda terhadap Kuantitas dan Kualitas Lem Tulang Ikan Pari Kampret (Gymnura micrura). [Skripsi]. Jurusan Perikanan, Fakultas Perikanan dan IImu Kelautan, Universitas Diponegoro, Semarang.

Widiyanto, A. 2011. Kualitas Papan Partikel Kayu Karet (Hevea brasiliensis Muell. Arg) dan Bambu Tali (Gigantochloa Dan Kelautan Tropis, 7 (1), 23-32.

Wahyudi, T. 2007. Perbandingan Kualitas Lem Tulang Ikan Pari Kembang (Amphotistus kuhlii) dan Lem Tulang Ikan Cucut Malam (Carcharias macloti). [Skripsi]. Universitas Diponegoro, Semarang.

Xiao, H., W. Wang, and Y.H. Chui. 2007. Evaluation of shear strength and percent wood failure criteria for qualifying new structural adhesives. Research Report. University of New Brunswick, Canada. 83p

Yuwono, T. 2003. Pengaruh Asam Klorida $(\mathrm{HCl})$ dengan Konsentrasi yang Berbeda Terhadap Kuantitas dan Kualitas Lem Tulang Ikan Pari Kelapa (Dasyatis sephen). Universitas Diponegoro, Semarang. 